\title{
Motor skills and functional characteristics of students of different somatotypes
}

\author{
Kolokoltsev M.M. ${ }^{1 \mathrm{ABCDE}}$, Iermakov S.S. ${ }^{2 \mathrm{ABCDE}}$, Prusik K. ${ }^{2 \mathrm{ADE}}$ \\ ${ }^{1}$ Department of the Physical Culture, Irkutsk National Research Technical University, Russia \\ ${ }^{2}$ Department of Tourism and Recreation, Gdansk University of Physical Education and Sport, Poland
}

Authors' Contribution: A - Study design; B - Data collection; C - Statistical analysis; D - Manuscript Preparation; E - Funds Collection.

\begin{tabular}{|c|c|}
\hline \multicolumn{2}{|l|}{ Abstract } \\
\hline Purpose: & $\begin{array}{l}\text { The purpose of the article is to study correlation of motor and functional characteristics of students of different } \\
\text { somatotypes. }\end{array}$ \\
\hline Material: & $\begin{array}{l}\text { it was examined first year students ( } n=577,17-18 \text { years old). All students were trained in discipline "Physical } \\
\text { education". It was carried out somatotyping. It was considered motor skills and functional characteristics of students. }\end{array}$ \\
\hline Results: & $\begin{array}{l}\text { it was determined the reliable differences in values of parameters of motor tests and functional characteristics of } \\
\text { students' organism. It is determined that by the end of the first year of study the positive dynamics is registered: } \\
\text { in sthenics (in two of seven motor tests); in asthenics (in four tests). It wasn't found the reliable positive changes } \\
\text { in group of hypersthenics. Students of sthenic and asthenic somatotypes have higher functional reserves of } \\
\text { cardiorespiratory system, than girls of hypersthenics somatotype. }\end{array}$ \\
\hline Conclusions: & $\begin{array}{l}\text { constitutional features of motor skills and functional parameters of students of different somatotypes allow to } \\
\text { concretize provisions of methodology of planning the individual differentiated training in discipline Physical } \\
\text { education. }\end{array}$ \\
\hline $\mathrm{V}$ & students, somatotypes, motor skills, functional fitness, physical education. \\
\hline
\end{tabular}

\section{Introduction}

The somatotype is relative (conditional) genetic marker which defines somatic and physical health of the person. The somatotype is criterion of health of the specific person $[1,2]$ and population in general [3]. It is impossible to consider features of morphofunctional condition of organism without its constitutional features [4].

The works concerning communication of somatotype with motor characteristics of person are of interest. It was noted the higher rates of physical fitness of representatives of macrosomic somatotype in group of children of the second childhood (engaged in circus art) in comparison with schoolgirls of the same somatotype (engaged in physical education at school) [5]. It was widely used the constitutional typology in fitness programs for correction of person's somatotype $[6,7]$ and rational organization of aerobics' group trainings of fertile age women [8-10].

Nowadays physical education trainings at school mean 14 types of motor loads. Such loads consider somatotype of school pupils. Somatotype defines significant amount of specific features of demonstration and dynamics the morphofunctional parameters [11].

Students with macrosomic somatotype relate to category of persons with low functional reserve of cardiovascular system. On the contrary, representatives of microsomic type have high functionality of this system. Features of morphofunctional condition of students' organism of different somatotypes should be considered during development of educational process creation algorithm in physical training [12].

Study of questions of somatotype's correlation has distinctive functional characteristics. It is the

\footnotetext{
(C) Kolokoltsev M.M., lermakov S.S., Prusik K., 2017 doi:10.15561/20755279.2018.0105
}

important direction of researches in the field of physical education with development of person's motor skills $[4,13]$. It allows to reveal weaknesses of the physical and functional skills of pupils, to make correction into training programs of physical education [14]. Negative characteristics of somatic and physical health parameters of Russian students sped up the research directed to study of integration of physical education and sport with constitutional typology [15-17]. Such methodological approach to physical education of youth is relevant and actual nowadays [18].

Hypothesis. Authors assume that received data concerning features of motor skills and functional characteristics' demonstration of organism of representatives of different somatotypes will promote development of individual and motor educational approaches in physical education classes.

The purpose of the research is to study correlation of motor and functional characteristics of higher education institution's students of different somatotypes.

\section{Material and methods.}

Participants. It was examined first year students ( $n=577$, age of 17-18 years) of Irkutsk National Research Technical University. All students belongs to main medical group according to health reasons (have no deviations in state of health). All students attended classes in discipline "Physical education". Participation in research does not violate rights and does not endanger students' wellbeing. The research is conducted according to ethical standards of committee on the rights of experiments of Helsinki declaration of 2008 [19].

Organization of research. At the beginning and the end of academic year was carried out pedagogical monitoring of parameters of motor tests in students of 
different somatotypes. Somatotyping of students was carried out according to scheme of M.V. Chernorutsky with calculation of Pinie index value according to the formula:

$$
(\mathrm{I})=\mathrm{L}-(\mathrm{P}+\mathrm{T}) \text {, }
$$

where $\mathrm{L}$ - is full length standing body $(\mathrm{cm}), \mathrm{P}-$ is body weight (kg), $\mathrm{T}$ - is chest circumference on exhalation (cm).

At index value $<10$ somatotype was evaluated as hypersthenic, in the range of index from 10 to 30 - is sthenic (N) and > 30 - is asthenic (A) [20].

For the characteristic of correlation of somatotypes with functional parameters were measured:

- $\quad$ heart rate before load (HR, beats / $10 \mathrm{sec}$ );

- heart rate after 20 squats per $30 \mathrm{sec}$ (HR, beats / $10 \mathrm{sec}$ );

- $\quad$ time of HR recovery (min) after 20 squats;

- $\quad$ systolic blood pressure (BPS), $\mathrm{mm} \mathrm{Hg}$;

- $\quad$ diastolic blood pressure (BPD), mm Hg.;

- vital lung capacity (VLC, l);

- dynamometry of wrists of both hands (kg).

It was calculated:

- $\quad$ Robinson index (IRob $=$ HRxBPS: 100 relative units),

- vital index (VI= VLC/BM, $\mathrm{ml} / \mathrm{kg})$, where $\mathrm{BM}$ - (body mass),

- $\quad$ strenght index (SI = is muscular strength of wrist / BMx100\%).

The main motor skills of students were evaluated. Tests were used: on high-speed endurance and agility (10 times shuttle run x $5 \mathrm{~m}$, sec); speed (20 m run without a pause, sec); high-speed and strength endurance of flexors of the body (set-up, times per $30 \mathrm{sec}$ ); strength and strength endurance of girdle of superior extremity muscles (hang on horizontal bar, sec); dynamic muscular strength of appendicular muscles (standing long-jump, $\mathrm{cm}$ ); active flexibility of backbone and hip joints (sit and reach, $\mathrm{cm}$ ); general endurance (5 min run, $\mathrm{m}$ ) [21].
Statistical analysis. Application programs "StatSoft Statistica 6.1", "Microsoft Excel" and the author's program complex "Analysis of Data of Physical Health of Population” (state registration program №2010612275, of 26.03.2010) were used for calculation of received data. Arithmetic mean value of parameters (M), mean-square deviation $(\sigma)$ and standard mistake $(\mathrm{m})$ were calculated. Evaluation of differences reliability of distinctions of average values of independent sample was carried out by parametrical methods with the help of Student's t-test on the basis of normal Gaussian distribution of the studied quantitative characteristic. Differences between values of parameters at level $\mathrm{p}<0,05$ considered statistically significant.

\section{Results.}

The sthenic (S) somatotype in examined girls was registered in 64,7\%. Girls of hypersthenic $(\mathrm{H})$ and asthenic (A) somatotypes meet less often $(9,9 \%$ and $25,4 \%$ respectively). The characteristic of motor skills in representatives of different somatotypes is presented in table 1.

There are differences between values of parameters of motor tests of girls of different somatotypes. Representatives of sthenic and asthenic somatotypes have higher rates in comparison with hypersthenic girls $(p<0,05)$ in the following tests: strength and strength endurance of muscles of girdle of superior extremity; high-speed and strength endurance of muscles of flexors of the body; dynamic muscular strength of girdle of inferior extremity; flexibility and general endurance. The best results are registered in asthenic $(p<0,05)$ in motor tests: strength and strength endurance of muscles of girdle of superior extremity; high-speed and power endurance of muscles of flexors of the body; dynamic muscular strength of girdle of inferior extremity and flexibility.

Table 1 demonstrates that to the end of training positive dynamics is registered: in sthenic - in two of seven tests (20 m run without a pause and 5 min run); in asthenic - in four tests (20 m run without a pause, hang,

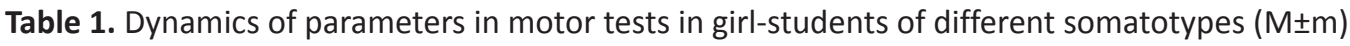

\begin{tabular}{|c|c|c|c|c|c|c|}
\hline \multirow{2}{*}{ Tests } & \multicolumn{3}{|l|}{ September } & \multicolumn{3}{|l|}{ Mai } \\
\hline & $H(n=57)$ & $S(n=373)$ & $A(n=147)$ & $H(n=57)$ & $S(n=373)$ & $A(n=147)$ \\
\hline Shuttle run (sec) & $22,8 \pm 0,43$ & $21,9 \pm 0,12$ & $21,7 \pm 0,13$ & $23,2 \pm 0,42$ & $22,2 \pm 0,17$ & $21,96 \pm 0,39$ \\
\hline $\begin{array}{l}20 \text { m run } \\
\text { without a pause } \\
(\mathrm{sec})\end{array}$ & $3,98 \pm 0,26$ & $4,62 \pm 0,17$ & $4,64 \pm 0,26$ & $3,68 \pm 0,08$ & $3,60 \pm 0,04^{* *}$ & $3,50 \pm 0,06 * *$ \\
\hline Hang (sec) & $7,59 \pm 0,52$ & $8,67 \pm 0,33 *$ & $9,92 \pm 0,5^{*}$ & $8,31 \pm 0,89$ & $8,73 \pm 0,35$ & $12,02 \pm 0,6 * *$ \\
\hline Sit-ups (times) & $20,01 \pm 0,91$ & $22,1 \pm 0,35^{*}$ & $23,5 \pm 0,51^{*}$ & $20,2 \pm 1,21$ & $22,61 \pm 0,5$ & $26,4 \pm 1,33 * *$ \\
\hline $\begin{array}{l}\text { Sit and reach } \\
(\mathrm{cm})\end{array}$ & $11,44 \pm 0,89$ & $14,29 \pm 0,53^{*}$ & $14,96 \pm 0,66^{*}$ & $13,53 \pm 0,72$ & $15,88 \pm 0,49$ & $14,67 \pm 0,81$ \\
\hline $\begin{array}{l}\text { Standing long- } \\
\text { jump }(\mathrm{cm})\end{array}$ & $135,1 \pm 4,01$ & $150,5 \pm 1,11^{*}$ & $157,8 \pm 1,69 *$ & $135,8 \pm 3,41$ & $152,2 \pm 1,29$ & $161,3 \pm 2,1$ \\
\hline 5 min run $(m)$ & $789,7 \pm 18,6$ & $860,4 \pm 14,1^{*}$ & $856,2 \pm 22,6^{*}$ & $775,5 \pm 42,5$ & $907,7 \pm 12,7^{* *}$ & $918,5 \pm 12,9 * *$ \\
\hline
\end{tabular}

Note. ${ }^{*}$ - statistically significant differences between somatotypes $(p<0,05) ; *_{-}^{*}$ statistically significant differences between examinations ( $p<0,05)$; Somatotypes: $\mathrm{H}$ - hypersthenic; $\mathrm{S}-$ sthenic; $\mathrm{A}-$ asthenic. 
sit-ups, 5 min run). In group of hypersthenics there are no reliable positive changes in any motor tests.

Features of the characteristic of functional parameters in representatives of different somatotypes are given in table 2.

In students with sthenic and asthenic somatotypes of key parameters' value (BP systolic, HR at rest per $10 \mathrm{sec}$; time of HR recovery after 20 squats per $30 \mathrm{sec}$ ) is less, than values of the same parameters in hypersthenics $(p<0,05)$. Robinson index in sthenics and asthenics is lower in comparison with hypersthenics. There are no reliable differences of BPD in girls of different somatotypes.

The lowest values of VLC parameters and muscular strength of wrists of both hands is registered in girls of sthenic and asthenic somatotypes. These girls have the highest values of VI and SI parameters (tab. 2).

\section{Discussion}

The physical education is effective mean of person's health maintenance and promotion at any age. Hypokinesia and hypodynamia of the studied youth [22] is followed by underdevelopment of motor skills, health deterioration [23, 24] and work of functional systems of organism [25, 26]. It is relevant to search new approaches to increase in efficiency of physical education trainings in higher education institutions on this background [12, $27,28]$.

Some authors suggest to determine somatotypes, i.e. to differentiate them according to extent of development of the total sizes of body: individuals with small body sizes are microsomatics (asthenics); macrosomatics (hypersthenics) are individuals with big sizes. Average position is held by mesosomatics (sthenics) [29]. The analysis of scientific and methodical literature shows that orientation of certain motor skills development of the person has to be based on somatotypes [17, 30, 31].

Our researches demonstrate that girls of sthenic and asthenic somatotypes have advantage over hypersthenics in such motor skills as: strength and strength endurance of muscles of girdle of superior extremity; high-speed and strength endurance of muscles of flexors of the body (fig. 1); dynamic muscular strength of girdle of inferior extremity; general endurance (fig. 2). It is confirmed by reliable values of parameters in the corresponding motor tests in students of sthenic and asthenic somatotypes in comparison with hypersthenics.

R.N. Dorokhov's methodology [32, 33] was used in our previous researches. Results demonstrated that students of mesosomatic and microsomatic somatotypes had better developed endurance, high-speed, strength and coordination skills. The somatotyping methodology of M.V. Chernorutsky was used in the given research. Results confirm earlier received data concerning correlation of motor and the morphofunctional parameters of person's somatotype.

There are researches about genotypic features of girls of different somatotypes to perception of physical loads [34]. The level of development of the main physical

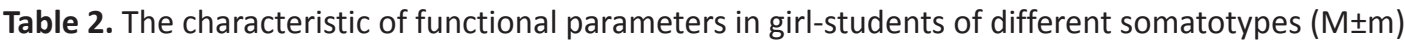

\begin{tabular}{|c|c|c|c|c|}
\hline Functional parameters & $\begin{array}{l}\text { Somatotypes } \\
\text { hypersthenic } \\
(n=57)\end{array}$ & sthenic $(n=373)$ & $\begin{array}{l}\text { asthenic } \\
(\mathrm{n}=147)\end{array}$ & $P<0,05$ \\
\hline Systolic blood pressure (BPS), $\mathrm{mm} \mathrm{Hg}$ & $109,8 \pm 0,93$ & $105,7 \pm 0,26 *$ & $105,0 \pm 0,42 *$ & $1-2 ; 1-3$ \\
\hline Diastolic blood pressure (BPD), $\mathrm{mm} \mathrm{Hg}$ & $70,25 \pm 0,91$ & $69,29 \pm 0,32$ & $68,91 \pm 0,58$ & \\
\hline Heart rate before load (HR, beats / $10 \mathrm{sec})$ & $11,9 \pm 0,06$ & $11,7 \pm 0,02 *$ & $11,3 \pm 0,04 *$ & $\begin{array}{l}1-2 ; 1-3 ; \\
2-3\end{array}$ \\
\hline $\begin{array}{l}\text { Heart rate after } 20 \text { squats per } 30 \mathrm{sec} \text { (HR, } \\
\text { beats / } 10 \mathrm{sec})\end{array}$ & $21,2 \pm 0,22$ & $21,0 \pm 0,07$ & $21,0 \pm 0,13$ & \\
\hline Time of HR recovery (min) after 20 squats & $1,58 \pm 0,05$ & $1,45 \pm 0,01 *$ & $1,48 \pm 0,03 *$ & $1-2 ; 1-3$ \\
\hline Robinson index, relative units & $78,4 \pm 0,67$ & $74,2 \pm 0,15 *$ & $71,2 \pm 0,22 *$ & $\begin{array}{l}1-2 ; 1-3 ; \\
2-3\end{array}$ \\
\hline Vital lung capacity (VLC, I); & $2667,2 \pm 31,2$ & $2663,5 \pm 10,1$ & $2616,4 \pm 20,5$ & \\
\hline Vital index, $\mathrm{ml} / \mathrm{kg}$ & $39,3 \pm 0,46$ & $47,3 \pm 0,14 *$ & $52,2 \pm 0,18 *$ & $\begin{array}{l}1-2 ; 1-3 ; \\
2-3\end{array}$ \\
\hline Dynamometry of the left hand, $\mathrm{kg}$ & $26,07 \pm 0,48$ & $23,7 \pm 0,15 *$ & $23,8 \pm 0,24 *$ & $1-2 ; 1-3$ \\
\hline Force index of the left hand, $\%$ & $39,1 \pm 0,44$ & $41,9 \pm 0,12 *$ & $47,5 \pm 0,15^{*}$ & $\begin{array}{l}1-2 ; 1-3 ; \\
2-3\end{array}$ \\
\hline Dynamometry of the right hand, $\mathrm{kg}$ & $27,4 \pm 0,51$ & $24,5 \pm 0,15 *$ & $24,7 \pm 0,26 *$ & $1-2 ; 1-3$ \\
\hline Force index of the right hand, $\%$ & $41,1 \pm 0,47$ & $43,3 \pm 0,16 *$ & $49,3 \pm 0,17 *$ & $\begin{array}{l}1-2 ; 1-3 \\
2-3\end{array}$ \\
\hline
\end{tabular}

Note. ${ }^{*}$ - statistically significant differences between somatotypes $(p<0,05)$ 
skills in preschool children has differences depending on somatotype. The best results in parameters of speed, endurance, flexibility, high-speed and strength tests are peculiar to girls of mesosomic and microsomic somatotypes. Girls of macrosomic somatotypes demonstrate the best results in research of muscular strength of wrists [35]. It is correlated with received data. Children of microsomatic and mesosomatic types have higher rates in comparison with macrosomatics: speeds of muscles contraction of girdle of inferior extremity; speed and strength of muscles contraction of both extremities [36].
Women of the second mature age (microsomatic type) have higher rates of vital index, general endurance, speed and coordination, low level of absolute strength's development [37]. It is correlated with received data.

In the end of pedagogical monitoring we have registered positive dynamics of parameters values in sthenics in two of seven motor tests. The increase in values of parameters in $20 \mathrm{~m}$ run without a pause was $22,0 \%$, in 5 min run was 5,5\%. Asthenics have increase in values of parameters in four tests $-20 \mathrm{~m}$ run without a pause was $24,5 \%$, in hang - was $21,1 \%$, in set-up was $12,3 \%$, in 5 min run was $7,2 \%$. In group of hypersthenics

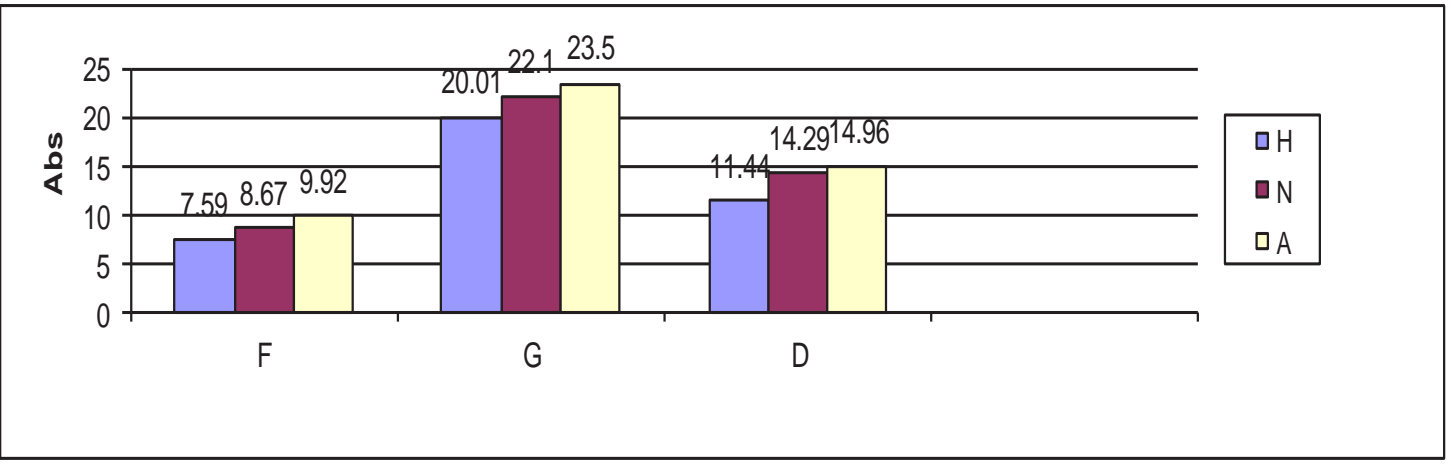

Fig. 1. The characteristic of motor skills in students of different somatotypes: $\mathrm{H}$ - hypersthenics; $\mathrm{S}-$ sthenics; $\mathrm{A}-$ asthenics; F - hang on horizontal bar; G - set-up; D - forward bend; Abs - absolute number.

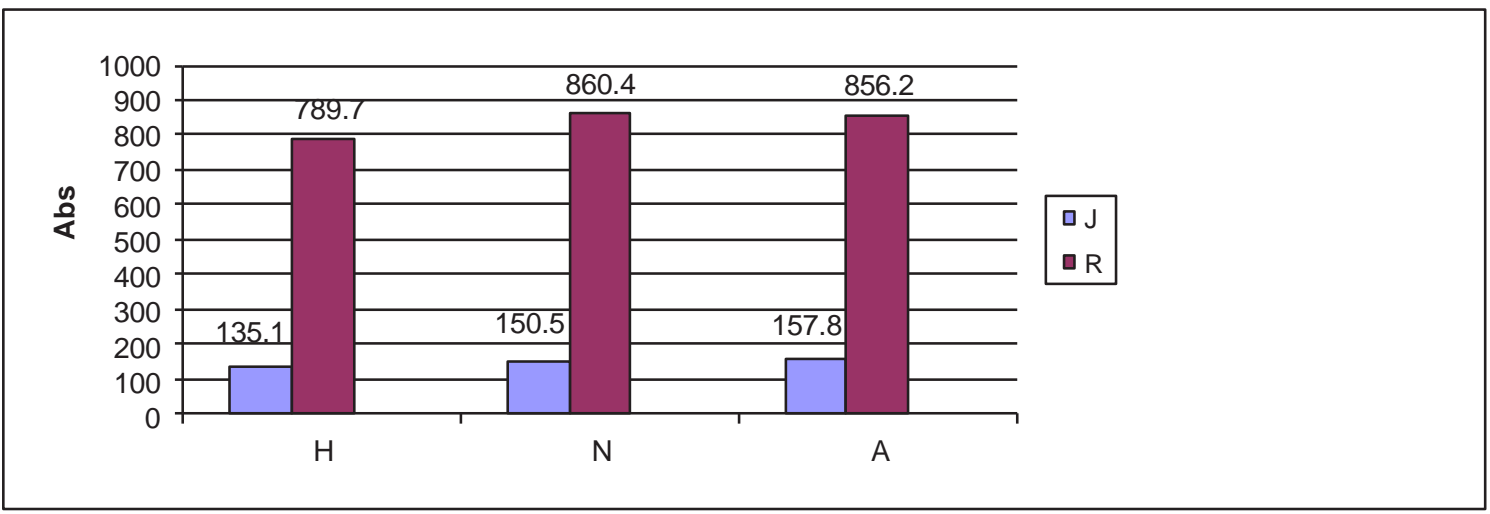

Fig. 2. The characteristic of dynamic force of girdle of inferior extremity and general endurance in students of different somatotypes: $\mathrm{H}$ - hypersthenics; $\mathrm{S}$ - sthenics; $\mathrm{A}$ - asthenics; J - long jump from the spot, cm; $\mathrm{R}-5 \mathrm{~min}$ run, $\mathrm{m}$.

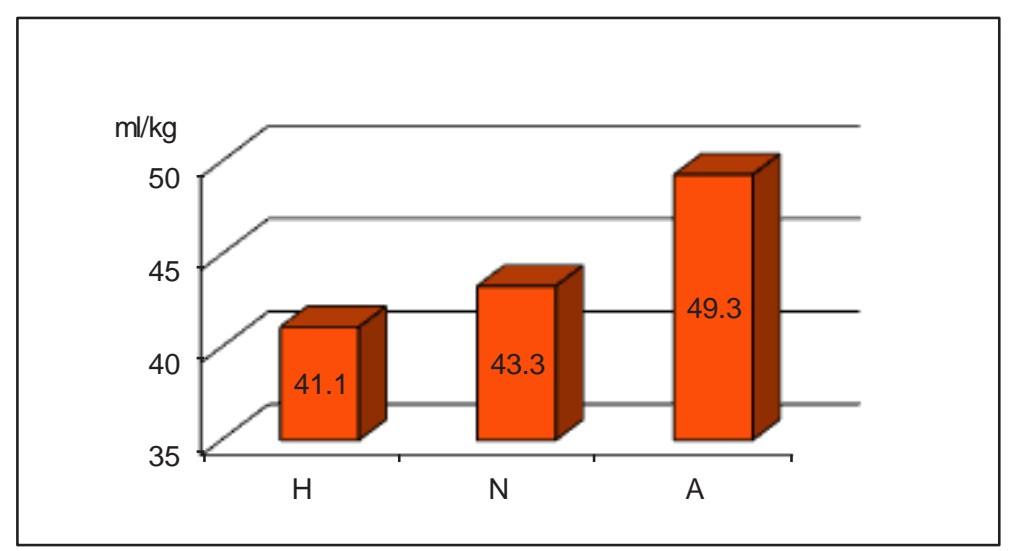

Fig. 3. The vital index in students of different somatotypes: $\mathrm{H}$ - hypersthenics; $\mathrm{S}$ - sthenics; $\mathrm{A}$ - asthenics 
$\%$

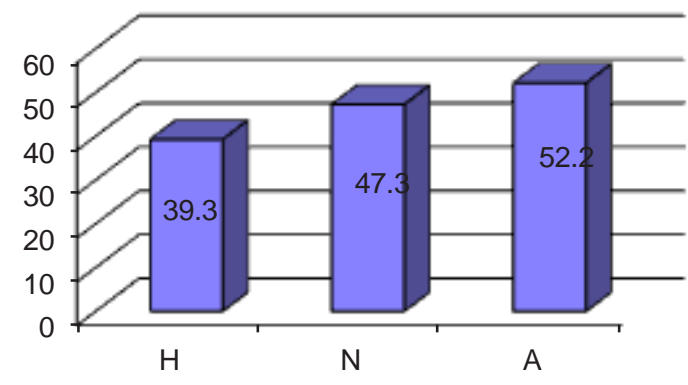

Fig. 4. The strength index of the right hand in students of different somatotypes: $\mathrm{H}$ - hypersthenics; $\mathrm{S}-$ sthenics; A asthenics.

there are no reliable positive dynamics of parameters values in any motor tests.

It is known that the functional systems of organism considerably provide performance of person's physical activity [38]. It is determined that reserves of cardiovascular system are higher in sthenics and asthenics in comparison with hypersthenics. Asthenics and sthenics have less HR at rest (per $10 \mathrm{sec}$ ) and time of HR recovery (after 20 squats per $30 \mathrm{sec})$, than hypersthenics $(\mathrm{p}<0,05)$. Robinson index was $5,7 \%$ lower in sthenics and $9,1 \%$ lower in asthenics in comparison with hypersthenics. Our data confirm results of researches [12, 37] concerning parameters' of reserve opportunities values of women cardiorespiratory system considerably depend on somatotype.

Girls of microsomatic type have low parameters' values of body length and weight, chest circumference. These girls have higher functionality of organism, in comparison with girls of macrosomic somatotype with higher rates of physical development [12].

High values of Robinson index and minute volume of blood circulation testify to heavy load on cardiovascular system of students of hypersthenic somatotype [39].

According to our data value of vital (fig. 3) and strength indexes of students' right hand wrist (fig. 4) have dynamics to increase from hypersthenic to asthenic somatotype.

Study of 7-16 years old schoolgirls testified that girls of macrosomic somatotype had higher level of absolute vital capacity of lungs. Girls of microsomatic type had low level of absolute vital capacity of lungs. However the vital index was authentically high in girls of microsomic somatotype [34]. These data is correlated with results of our researches concerning absolute and relative vital capacity of students' lungs. Low level of relative values of vital capacity of lungs leads to underdevelopment of aerobic endurance of girls. Low level of the strength index parameter characterizes underdevelopment of muscular system of girls. It is necessary to use the differentiated approach in development of endurance and strength in students of hypersthenic somatotype at physical education classes. Also girls need to perform regular independent physical exercises in extracurricular time. Such loads should to be coordinated with teachers.

The research allow to correct pedagogical process of the individual differentiated physical training of students with use of constitutional typology. Results of our researches and data of other authors allow to make the following recommendations:

1 ) it is necessary to use sport and game technologies, endurance exercises, swimming, slow long run, fitness aerobics, breathing exercises planning educational process on physical training for girls of hypersthenic somatotype;

2) girls of asthenic somatotype should to pay more attention to speed development as physical quality.

\section{Conclusions}

1. Students of 17-18 years old of three somatotypes (asthenic, sthenic, hypersthenic) have distinctive parameters of motor skills and reliable difference $(p<0,05)$ in a number of functional characteristics of respiratory, cardiovascular and muscular systems of the body.

2 . The received data concerning constitutional features of motor skills and functional body characteristics of students of different somatotypes allow to concretize provisions of methodology of planning of individually differentiated training in discipline "Physical education" at higher education institution.

\section{Conflict of interests}

The author declares that there is no conflict of interests 


\section{References}

1. Kalmykova EM, Kharlamov EV. Characteristics of the level of the phisical health and physican fitness of the medicos subject to the somatotype by properly sized variation level. Medicinskij vestnik Iuga Rossii, 2011;4: 33-38. (in Russian)

2. Jagiello W, Kruszewski A. Morphological diversification of competitors training Greco-Roman style of wrestling. Archives of Budo. 2009;5: 147-153.

3. Tunnemann H. Evolution and adjustments for the new rules in wrestling. Psychophysiological International Journal of Wrestling Science. 2013;3(2): 94-105.

4. Kalmykova EM, Kharlamov EV. Professional-applied physical preparation of medical students taking into account constitutsional and typological features. Medicinskij vestnik Iuga Rossii, 2012; 3:29-32. (in Russian)

5. Medvedeva OA, Aleksanianc GD, Grebenik AV. Characteristics of physical readiness of children of the second childhood period, working in circus arts, depending on the somatotype. Sovremennye problemy nauki $i$ obrazovaniia.2017;1: 20-25. (in Russian)

6. Romanenko NI. Influence of fitness studies on physical preparedness of middle-aged women of various somatic tupes. Kul'tura fizicheskaia i zdorov'e, 2011;5 (35):35-38. (in Russian)

7. Aftimichuk OE, Varvarich AV. Muscular Imbalance Correction in the Power Fitness Traini. European Journal of Physical Education and Sport, 2013;1(1): 4 - 14.

8. Kharlampenkova IuA, Dardanova NA. Consideration of somatic features of women at childbearing age in the organization of training on various kinds aerobics. Uchenye zapiski universiteta im. P.F. Lesgafta, 2012;3:184-187. (in Russian)

9. Jagiello W, Sawczyn S, Jagiello M. The subjective profile of positive health and survival abilities in women differing as to physical activity. Archives of Budo. 2012;8(4):219-24.

10.Smulski W, Wolska B, Jagiello W, Sawczyn S. The correlation of general and sport-specific preparation indices of elite female judo competitors with their age-somatic characteristics. Archives of Budo. 2011;7(4):233-8.

11.Blinkov SN, Levushkin SP, Kosikhin VP. Change of parameters of the physical condition of rural schoolgirls aged 7-17 years of different somatotype under the influence of the motor modes of various orientations. Uchenye zapiski universitetata im. P.F.Lesgafta, 2015; 1 (119):42 - 48. (in Russian)

12.Priymak S G, Terentieva N O. Somatologic characteristics of biathlon students' body constitution in predicting of their successfulness. Pedagogics, psychology, medical-biological problems of physical training and sports, 2017; 21(4): 192199. doi:10.15561/18189172.2017.0408

13.Klimczak J, Kalina RM, Jagiello W. Fun forms of martial arts in diagnosing and reducing aggressiveness - mental effects of a one-day course for Polish animators of sport. Health and Martial Arts in Interdisciplinary Approach. 2015:187-9.

14.Dorontsev AV, Kozlyatnikov OA. Structure of correlation of level of physical fitness and parameters of standard functional tests at students of muscular-digistive type of constitution. Uchenye zapiski universitetata im. P.F.Lesgafta, 2017. №6(148). 62-66. (in Russian)

15.Appak GA. Individual-typological approach to physical training for students 17-18 years old with various diseases. Adaptivnaia fizicheskaia kul'tura, 2012;1 (49): 42-44. (in Russian)

16. Vartanova OT, Yevtushenko AV, Nor-Arevyan KA, Sidorova EN. Some constitutional features of residents in the Rostov region. Astrakhanskij medicinskij zhurnal, 2013; 1: 48-50. (in Russian)

17.Kolokoltsev MM. Somatotypologic estimation of studentsyouths with the different level of the functional state. Gigiena i sanitariia. 2017;5:478-483. (in Russian)

18.Rodina MV, Callagova RB. Principles of construction individual motoring in improving physical training women of the second coming age. Fundamental'nye issledovaniia, 2012;12 (2):355-359. (in Russian)

19.WMA Declaration of Helsinki - Ethical Principles for Medical Research Involving Human Subjects. Retrieved from http://www.ub.edu/recerca/Bioetica/doc/Declaracio_ Helsinki_2013.pdf

20.Fefelova VV, Koloskova TP, Fefelova YA, Kazakova TV, Sergeeva EY. Effect of food load on activities of enzymes of the main metabolic pathways in blood lymphocytes in girls with different anthropometric parameters. Bulletin of Experimental Biology and Medicine, 2015;159(3):309-313.

21.Landa BKh. Technique of integrated evaluation of physical development and physical fitness. Moscow; 2000. (in Russian)

22.Bodnar IR, Stefanyshyn MV, Petryshyn YV. Assessment of senior pupils' physical fitness considering physical condition parameters. Pedagogics, psychology, medical-biological problems of physical training and sports, 2016; 20(6): 9-17. doi:10.15561/18189172.2016.0602

23. Adyrkhaev SG. Modern technology of physical education of disabled students in conditions of inclusive education. Pedagogics, psychology, medical-biological problems of physical training and sports, 2016; 20(1): 4-12. doi:10.15561/18189172.2016.0101

24. Teixeira TF, Alves RD, Moreira AP, Peluzio M. Main characteristics of metabolically obese normal weight and metabolically healthy obese phenotypes. Nutr Rev. 2015; 73 (3):175-190.

25.Cook MD, Martin SA, Williams C. Forced treadmill exercise training exacerbates inflammation and causes mortality while voluntary wheel training is protective in a mouse model of colitis. Brain, Behavior, and Immunity, 2013;33:46-56. doi:10.1016/j.bbi.2013.05.005.

26.Ivashchenko OV. Special aspects of motor abilities development in 6-10 years' age girls. Pedagogics, psychology, medical-biological problems of physical training and sports, 2017; 21(3): 105-110. doi:10.15561/18189172.2017.0302

27.Dorokhov RN. Constitutional diagnosis of children of 5-8 years old. Uchenye zapiski universitetata im. P.F.Lesgafta, 2012. №3(85). C.81-86. (in Russian)

28.Kolumbet AN, Dudorova LYu. Correction of physical education program for technical higher educational establishment girl-students on the base of their health parameters. Physical education of students, 2016; 20(6): 1825. doi:10.15561/20755279.2016.0602

29.Nikitiuk BA. Correlation of the general, private and regional in the doctrine about person's constitution. Novosti sportivnoj i medicinskoj antropologii, 1990;2:14-40. (in Russian)

30.Shepelenko TV, Kozina ZhL, Cieslicka M, Prusik K, Muszkieta R, Sobko IN, Ryepko OA, Bazilyuk TA, Polishchuk SB, Osiptsov AV, Kostiukevych VM. Factorial structure of aerobics athletes' fitness. Pedagogics, psychology, medicalbiological problems of physical training and sports, 2017; 21(6): 291-300. doi:10.15561/18189172.2017.0606

31.Martirosov EG. Morphogenetic problems of sports selection. Moscow; 1989. (in Russian)

32.Kolokoltsev MM. Characteristic of locomotor abilities of male students of different constitutional types. Vestnik 
IrGTU, 2014; 11(94):338-343. (in Russian)

33.Kolokoltsev MM, Koypysheva EA. Motor abilities of technical female students of different somatotypes Vestnik IrGTU, 2014;1 (84):210-215. (in Russian)

34.Aksenova AN. Age regularities and features of development of the leading motor skills in schoolgirls according to somatotype development. Sovershenstvovanie sistemy fizicheskogo vospitaniia i sporta $v$ usloviiakh promyshlennykh regionov Sibiri, 2004;1: 28-33. (in Russian)

35.Korenevskaia AA, Prokof'eva VN, Kuznecov VI. Physical preparedness and somatic features of organism of preschool children Teoriia i praktika fizicheskoj kul'tury, 2009;8:59-64. (in Russian)

36.Polityko IuE. Anatomic components of somatotype of younger school students as basis of development of health saving technologies. Cand. Diss. Sankt Petersburg; 2009. (in Russian)

37.Romanenko NI. Morphofunctional status of women of different somatotypes aged 35-45 engaged in fitness. Fizicheskaia kul'tura, sport - nauka i praktika, 2012;2:4649. (in Russian)

38.Egorycheva EV. Assessment of physical development, functional state and physical readiness of students with deficiency of body weight. Uchenye zapiski universitetata im. P.F.Lesgafta, 2014. №2 (108. C.66-70. (in Russian)

39. Sharypova NV, Sveshnikov AA. Somatotype influence to adaptive reactions of body in examinational stress. Sovremennye problemy nauki i obrazovaniia, 2007;6:59-64. (in Russian)

\section{Information about the authors:}

Kolokoltsev M.M. (Corresponding author); http://orcid.org/0000-0001-6620-6296; mihm49@mail.ru; Irkutsk National Research Technical University; ul. Lermontov 83, Irkutsk, 664074, Russia.

lermakov S.S.; http://orcid.org/0000-0002-5039-4517; sportart@gmail.com; Department of Tourism and Recreation, Gdansk University of Physical Education and Sport; Kazimierza Górskiego 1, 80-336 Gdańsk, Poland.

Prusik K. (Prusik Katarzyna); http://orcid.org/0000-0002-2960-5105; Department of Tourism and Recreation, Gdansk University of Physical Education and Sport; Kazimierza Górskiego 1, 80-336 Gdańsk, Poland.

Cite this article as: Kolokoltsev MM, Iermakov SS, Prusik K. Motor skills and functional characteristics of students of different somatotypes. Physical education of students, 2018;22(1):31-37. doi:10.15561/20755279.2018.0105

The electronic version of this article is the complete one and can be found online at: http://www.sportedu.org.ua/index.php/PES/issue/archive

This is an Open Access article distributed under the terms of the Creative Commons Attribution License, which permits unrestricted use, distribution, and reproduction in any medium, provided the original work is properly cited (http://creativecommons.org/licenses/by/4.0/deed.en).

Received: 19.12.2017

Accepted: 12.01.2018; Published: 27.02.2018 